\title{
Larvae of Belonepterygion fasciolatum (Plesiopidae: Acanthoclininae)
}

\author{
MICHELLE N. YERMAN* AND JEFFREY M. LEIS \\ Ichthyology, Australian Museum, 6 College Street, Sydney NSW, 2010, Australia \\ michelle.yerman@austmus.gov.au
}

\begin{abstract}
Larvae of Belonepterygion fasciolatum (in the plesiopid subfamily Acanthoclininae) are described based on two postflexion, pelagic specimens from Espirito Santo, Vanuatu (5.7 mm SL) and Magnetic Island, Great Barrier Reef, Australia (6.3 mm SL), as well as two settled individuals (9.4 and $11.9 \mathrm{~mm}$ SL) from One Tree Island, Great Barrier Reef, Australia. Distinct morphological characteristics of acanthoclinins form early in development (c. $6 \mathrm{~mm} \mathrm{SL}$ ), including weak head spination limited to a single opercular spine, a large oblique mouth and three unbranched lateral lines. Dorsal and anal fins have many more spines than soft rays, dorsal and anal fin spines have thickened fleshy pads distally, the body is relatively slender with a deep, short caudal peduncle. Pigmentation consists of melanophores more-or-less evenly distributed across the trunk and head as well as a pale brown background (not obvious melanophores, the colour of skin and muscle) on the body that intensifies with growth. These are the first tropical acanthoclinin larvae to be reported. For reasons that are unclear, larvae of tropical and warm-temperate acanthoclinin species are rare in collections, but cool-temperate acanthoclinin larvae can be abundant.
\end{abstract}

YeRMAN, Michelle N., \& JeFFrey M. LeIS, 2011. Larvae of Belonepterygion fasciolatum (Plesiopidae: Acanthoclininae). Records of the Australian Museum 63(1): 79-83.

The plesiopid subfamily Acanthoclininae (formerly considered a separate family, see Mooi, 1993) consists of 13 species in four genera of small $(210 \mathrm{~mm}$, max. standard length), Indo-Pacific reef-associated fishes. Two of the genera, Acanthoplesiops (Regan) and Belonepterygion (McCulloch) are found on shallow tropical coral and rocky reefs. Of the other two, Beliops (Hardy) is found in both tropical and temperate areas whereas Acanthoclinus (Jenyns) is confined to temperate regions of Australia and New Zealand (Hardy, 1984; Neira, 1998; Smith-Vaniz \& Johnson, 1990). The single species of Belonepterygion is distinguished from those of Acanthoplesiops and Beliops by the presence of three lateral lines compared to one in the latter two genera, and from Acanthoclinus by dorsal and anal-fin spine and ray counts (Smith-Vaniz \& Johnson, 1990).
Acanthoclinin early-life history is poorly known, but seems to be broadly similar to that described for other plesiopid subfamilies (Neira, 1998; Leis \& Trnski, 2004). Both ovarian and spawned eggs have been described for Belonepterygion fasciolatum (Ogilby) (Mooi, 1990; Gill \& Mooi, 1993) while only spawned eggs are described for Acanthoclinus littoreus (Forster), formerly recognized as two species, namely Acanthoclinus quadridactylus (Bloch \& Schneider) and Acanthoclinus trilineatus (Griffin) (Smith-Vaniz \& Johnson, 1990). Spawned eggs are of moderate size (c. 1.4-1.7 mm diameter) and are bundled as demersal, spherical egg masses $(5-8 \mathrm{~cm}$ in diameter) held together by adhesive threads (Jillet, 1968a,b; Johnson, 1984; Mooi, 1990). The threads are attached evenly on eggs in both species, with $B$. fasciolatum having twice as

* author for correspondence 